\title{
Course design, action research and the use of computers: challanges in an ESP course $^{1}$
}

\author{
Desenho de curso, pesquisa-ação e o uso do \\ computador: desafios num curso de línguas \\ para fins específicos
}

Silvia Matravolgyi Damião*2

Instituo Tecnológico de Aeronáutica

São José dos Campos - São Paulo / Brasil

\begin{abstract}
This paper presents the results of an action research project that focused on the design and teaching of an ESP course and on the collaborative construction and development of a website. In the first year of the study, the course plan was modified due to the feedback given by the students and the same happened to the site, which was uploaded and modified according to the students' productions within the period. The course plan was reformulated in the second year of the study based on the experience acquired in the first year, and tasks were introduced to fulfill the students' academic and future professional needs. At the end of the second year of the study, it was possible to confirm that the course plan, with the modifications that were introduced, was adequate, and that the site reflected the tasks prepared by the students within the period, therefore reaching the objectives proposed at the beginning of the study. It was also possible to propose new directions for ESP teaching at the Institution where the research was carried out.
\end{abstract}

KEYWORDS: English for Specific Purposes, action research, computers in education.

RESUMO: Este artigo descreve os resultados de uma pesquisa-ação que teve como objetivos desenvolver e acompanhar um curso de linglês para fins específicos e sua docência, bem como a construção e desenvolvimento de um website. No primeiro ano do trabalho, o plano de curso foi modificado, devido ao retorno dado pelos alunos e o mesmo aconteceu com o site, que foi sendo alimentado e modificado de acordo com as produçóes dos alunos no período. O plano de curso

\footnotetext{
*silmdamiao@gmail.com

${ }^{1}$ Instrumental e ESP são utilizados como sinônimos neste artigo.

${ }^{2}$ Este trabalho foi orientado pela Profa. Dra. Rosinda de Castro Guerra Ramos (PUCSP).
} 
foi reformulado no segundo ano do estudo, com base na experiência adquirida no ano anterior, e tarefas foram introduzidas para ir ao encontro das necessidades acadêmicas e futuras necessidades profissionais dos alunos. Ao final do segundo ano da pesquisa, foi possível confirmar que o plano de curso, com as modificações implementadas, era adequado e que o site refletia as tarefas feitas pelos alunos durante o curso, confirmando-se, assim, os objetivos propostos no início da pesquisa. Também foi possível propor novos encaminhamentos para o ensino de inglês para fins específicos na instituição onde a pesquisa ocorreu.

PALAVRAS-CHAVE: Inglês para fins específicos, pesquisa-ação, uso de computadores na educação.

\section{Introduction}

Some issues related to education, such as the ones which consider the importance of looking for new ways of teaching and of learning in post modernity and which accept the many possibilities of incorporating new technologies into the instructional environment, can be associated with English Language Teaching (ELT) in general and to English for Specific Purposes (ESP) in particular.

If we take into consideration that most of the students who begin their undergraduate studies nowadays were born and brought up surrounded by information and communication technological devices and have incorporated their use into their daily life, we cannot ignore the importance of including such technological devices into the educational environment. Also, if knowledge is understood as a social construct, learning as a social process and teaching is not detached from the environment, then it is possible to admit that the educational context in which we live nowadays enables the development of different actions in which computers, and their different uses, may represent much more than mere tools to be used for gathering data or for communicating. According to Ramal (2002), computers used in education may conquer the status of a cognitive environment, of a mediating technological device by means of which the world can be seen and knowledge can be built. Based on this new educational concept and having it as its starting point, I associate the incorporation of computers as an educational tool to ESP teaching and learning.

More specifically, in this paper, I discuss the final results of my doctoral research project. ${ }^{3}$ The study, which is defined as an action research (CROOKES,

\footnotetext{
${ }^{3}$ The first steps of the research were presented in AILA 2005 - where the author of this paper was one of the awardees of the Solidarity Award.
} 
1993; BURNS, 2005, among others), aimed at focusing on the design and teaching of a face-to-face ESP course for first year undergraduate engineering students, and on the collaborative construction, development and maintenance of the course's website. The course design was based on Graves' (2000) framework of course development processes and the computer was incorporated to its design in the light of the work of Warschauer (1998; 2000), Ramal (2002) and Chapelle (2003). In the first year of the study, the course plan was modified due to the feedback given by the students by means of a continued needs analysis process (DUDLEY EVANS; St. JOHN, 1998); a rights analysis process (BENESCH, 1999; 2001); and also by means of negotiation (BREEN; LITTLEJOHN, 2001). The same happened to the site, which was uploaded and modified according to the students' productions within the period. The course plan was then reformulated in the second year of the study in the light of the experience acquired in the first year, and tasks (ELLIS, 2003; CHAPELLE, 2003) were introduced to fulfill the students' academic and future professional needs, identified at the beginning of the study. At the end of the second year of the study, it was possible to confirm that the course plan, with the modifications that had been introduced, was adequate and that the site reflected the tasks prepared by the students within that period, therefore reaching the objectives proposed at the beginning of the study. It was also possible to propose new directions for ESP teaching at the Institution where the research was carried out.

\section{An overview of ESP}

For such authors as Hutchinson and Waters (1987) and Bloor (1997), the main issues related to ESP in teaching actually began in the 1960s. Until about the end of the Second World War there was no questioning as for the reasons for studying a foreign language. Knowing more than one's own mother tongue was considered a synonym of good background. When the United States began to dominate the economical relationships in the western world, the use of the English language began to be regarded differently. It was then that it became an internationally accepted language not only in commercial transactions but also in business and in the academic environment. As a consequence, a new approach to language teaching began to be considered in the early sixties of the last century, once the students' needs started to be taken as very important in the design of a language course. At that time, it became evident that people did not study a foreign language just for the pleasure of knowing it or as a symbol of social status 
within the community; language learning needs began to be seen as essential to the design of language courses and, consequently, deadlines started to be established in order to reach such needs.

To Hutchinson and Waters (1987), ESP can be regarded as an approach in which "all the decisions as to content and method are based on the learner's reason for learning. (p.19)" Robinson (1991) also points out that what differentiates courses based on an ESP approach from general English teaching courses is that the former are always designed to a specified audience, taking this audience's needs into consideration, no matter if these needs are professional, academic or personal. For her, ESP is "an enterprise involving education, training and practice and drawing upon three major realms of knowledge: language, pedagogy and the students'/participants' specialist area of interest" (ROBINSON, 1991, p.1). She also establishes some criteria to define an ESP course. The first one is that an ESP course should be "goal directed", which means that it is always taught to students who actually need the language for work or for studies. The second criterion considers the relevance of needs analysis. This procedure aims at verifying, as precisely as possible, what the students actually need in the course. Besides these criteria, the author points out to some other relevant aspects for an ESP course, such as an established length of time for the course and the fact that ESP students are normally adults or young adults and therefore usually have some background knowledge of the language. Still according to her, another characteristic of such courses is that, although it is normally said that ESP courses must consider specialist terminology according to the students' area of studies, the activities in which students get engaged in may be considered more important than specific language.

In a conference held at the $5^{\text {th }}$ Latin American ESP Colloquium, Bloor (1997) analysed the effects of the new information and communication technologies, more specifically the computer, and its influence in education and in ESP. For her, teachers who work with ESP must be aware of the changes in the world. They should also consider the students' needs, which may be changing as new technologies are incorporated into people's everyday life. Therefore, teachers must be prepared for the challenge of incorporating new technologies both as an instructional tool and as a way of using the English language as a means of communication in discourse communities with whom students and teachers may wish to interact.

Finally, Dudley Evans and St. John (1998) define ESP by making a distinction between absolute and variable characteristics within the approach. 
For them, the two absolute characteristics are that ESP courses are always designed to meet the students' needs and that the methodological choices of the course, and the activities in it, occur having in mind the discipline the course serves; in turn, the variable characteristics are the following: normally, ESP courses are prepared for adult or young adult students who already have some knowledge of the foreign language; theses courses usually take place in the working context or at university, although they are sometimes used with secondary level students; the methodological choices may differ from that of General English courses; and the courses may be designed having a specific discipline in mind.

Dudley Evans and St. John's (1998) definition of ESP does not differ from the definitions presented by other authors who work in this field. All of them, in one way or another, seem to agree in many aspects such as the relevance of needs analysis in any ESP course and the importance of knowing the target situation, the instructional environment and the students. However, Dudley Evans and St. John add a new perspective to the understanding of ESP courses when they propose a continuum in the teaching of English as a foreign language which "runs from clearly definable General English courses through to very specific ESP course (p. 8)." The first position in the continuum (Position 1) usually represents general courses, which do not have a well defined target audience or specified needs to be fulfilled and are not concerned as to the instructional context in which the course will take place. Position 5 , the last position of the continuum, on the other hand, describes the opposite, i.e., it represents a course tailored to a very specific audience and context. The intermediary positions in the continuum present characteristics that may vary in terms of the skill (or skills) being focused, the group type (homogeneous or not), the discipline or the profession.

In the light of these authors' continuum, the course analysed in this study can be situated in a mid position of the continuum, which means it is neither a General English course nor a totally specific course related to a very particular area (e.g. civil or mechanical engineering). It is an academic course which also considers future professional needs (i.e., the general needs of future engineers); it is based on common core language and skills and it considers engineering as a broad professional area. It is possible to add to this analysis Bloor's (1997) view of the importance of incorporating technological resources to specific instructional contexts. It is also possible to associate Ramal's (2002) understanding of the use of the computer as a representation 
of a cognitive environment, of a mediating technology through which the world can be seen and knowledge can be built.

\section{A brief overview of ESP in Brazil}

The trajectory of ESP in Brazil is well described in the work of Celani et al. (1998), Celani (2005), Ramos (2005) and Ramos (2008). In the early days of the Brazilian ESP Project, a project that dates back to the 1970's, that began under the coordination of a group or researchers from PUC-SP, ${ }^{4}$ and involved most of the federal universities in Brazil, most of the work on ESP in the country was developed around the reading skill. This was due to the results of the needs analysis study that had been conducted at the beginning of the project which indicated that most university students at that time needed the English language to read specialized materials in their area of studies. That is why, for many years, ESP in Brazil was associated with the teaching of the reading skill. It was only recently that this myth was broken thanks to research done in the area of needs analysis, such as the ones by Pinto (2002), Cardoso (2003) and Carvalho (2008), among others. In a paper published by Ramos (2004) the pedagogical importance of implementing genre in the EFL classroom was considered and a practical proposal was presented. The author broke the old paradigm of a skill based syllabus and introduced the view of a genre based approach to ESP teaching. This means that at present there is a move in the country from associating ESP to an approach that deals with one skill at a time - mainly reading - to understanding it in a broader sense (RAMOS, 2005; RAMOS, 2008, among others). Nowadays the studies in the area of ESP in Brazil consider different ways in which genres can be exploited.

\section{Computers and English Language Teaching}

According to Chapelle (2003), just as many English language teachers differ in their methodological approaches to teaching, research about the development and spread of technology in applied linguistics also vary. The author discusses three different perspectives of the contributions of technology to society and its implications to the teaching and learning of EFL: the technologist vision; the social pragmatist vision; and the critical analyst vision.

${ }^{4}$ Pontifícia Universidade Católica de São Paulo (Catholic University of São Paulo). 
In the technologist vision, the focus of teaching is on the technological potentials offered by the new and modern technological resources, i.e., the computer. In other words, "teachers and researchers should be educated about possibilities that could improve or change their work" (CHAPELLE, 2003, p.10). This means that the technological resources, more specifically, the computer, must be incorporated into the teaching and learning process. In the social pragmatist vision, the focus changes to the use that teachers and students can make of the different technological resources. This means that, in this perspective, we move from a merely technical view that only considers the benefits of the machine to a vision that also considers the human being, i.e., that focuses both on the benefits and on the constraints that come with the use of computer. The relevance of this perspective to ELT is on the possibility that teachers and researchers have of evaluating pros and cons of a certain technological resource to their context. Finally, in the critical analyst vision, the use of computers cannot be understood as a sine qua non condition to the social evolution, as in the other perspectives. As Chapelle (2003) points out, the main focus in this perspective is on the questioning that arises as for the appropriateness (or lack of appropriateness) of the use of technological resources to ELT. This means that "teachers and researchers should be critically aware of the connection between technology and culturally-bound ideologies (p.10)".

Based on elements of these three different visions, she proposes a balanced view of the future of ELT, grounded on elements of the three visions. And it is this balanced view that I use in this research, i.e., I assume that the computer, and its various uses, is part of modern society. Therefore, it is not possible to deny its existence, and there is no reason not to incorporate it to the language teaching and learning process. Also, as stated by Ramal (2002), computers in education are not mere tools for storing information or for communicating. They assume a new cognitive role, they become mediating technology by means of which we can see the world and build knowledge.

\section{The Methodological Option: action research}

Action research is a methodology that can be applied to different research areas such as Education, Social Services and Business (THIOLLENT, 2004). Three great movements in action research are described by McKernan (1991) in the last fifty or sixty years: technical-scientific, practical-deliberativeinterpretivist, and critical-emancipatory. According to Crookes (1993), at present, it is possible to see elements of these three approaches in research that 
is based on action research and, as mentioned by Burns (2005, p. 248), "current interpretations of action research vary along a practical-critical continuum. Both types are valuable to the field of language teaching...". This may well explain the methodological choice in this study as the action research I carried out was embedded in the three elements described by McKernan (1991). It was a technicalscientific research (Type 1), because I tried to improve my own teaching and I also to tried to meet my students' needs; the course itself and the classroom were used as the place where data were collected for the development of the research and the students were involved in the process all the time. Therefore, it was also a practicaldeliberative action research (Type 2); finally, it could be understood as a criticalemancipatory research too (Type 3) because the research was not restricted to finding the solution (or looking for an answer) to a problem that had been identified at the beginning of the study. I looked for new proposals to the course in a critical way. For that reason, the research took the environment into consideration and it also took into account the students' needs and wants (HUTCHINSON; WATERS, 1987; DUDLEY EVANS; St. JOHN, 1998), their rights (BENESCH, 1999; 2001) and the fact that they were individuals inserted in a social, historical and cultural context and whose participation was essential for the development of the research. According to Crookes (1993, p. 137), "the conducting of action research as a means of critical reflection on teaching and on the sociopolitical context in which teachers find themselves has the potential to be a major component in the continuing struggle to improve SL teaching."

One of the distinguishing characteristics of action research is its cyclic nature or, as described by Kemmis and Mc Taggart (1988 apud BURNS, 2005), its definition of "a self-reflective spiral" which involves four movements: planning, action, observation and reflection. Such model can be associated with Dudley Evans and St. John's (1998) continued needs analysis model for ESP courses and to the right's analysis model, as analysed by Benesch (1999). The different steps of action research form a cycle in which one step influences, modifies and / or interferes in the other steps. The same happens to needs analysis and also to rights analysis, because their results influence, modify and / or interfere in the course design and in its planning, reflecting on the course itself, which, in turn, is re-defined by the continued needs and rights analysis processes, thus also forming a cycle. As put by Van Lier (1996, p. 34) "the steps and cycles [in action research] do not happen in a sequential and successive fashion (...) they are simultaneous strands that are braided together as one goes along. I might think about planning while observing, reflect while planning, revise my plan while acting, and so on." 
Based on this theoretical background on action research, I developed a scheme to illustrate the trajectory of my research, which occurred in four cycles, as shown below:

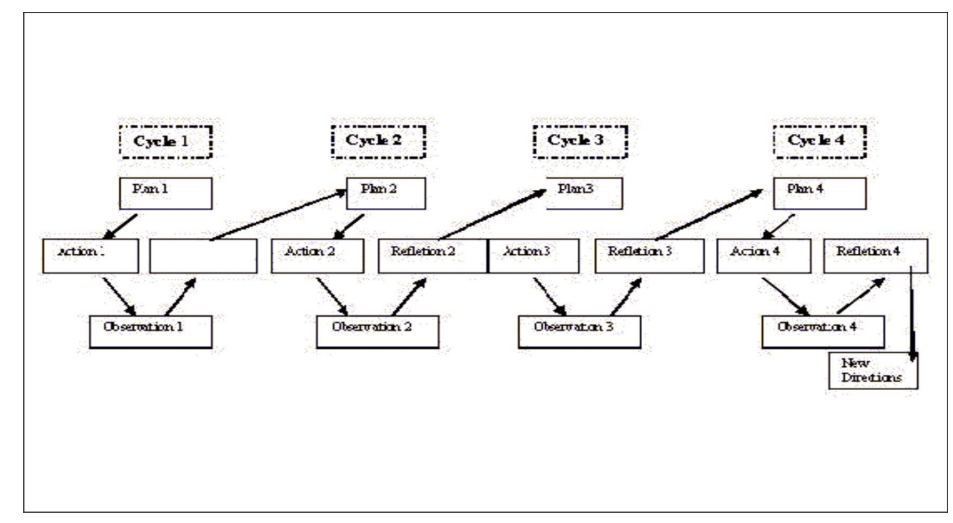

FIGURE 1 -The four cycles of the action research.

The ESP course in this study was offered as a regular discipline in an Engineering College. The English course was compulsory at that time for the first year students and totals 96 hours distributed in 3 classes a week for two semesters. The data were collected for two years, which means that two different groups of students participated in the study. The data collected in the first year of the research and the results observed in the period influenced the course design for the second year. Each one of the four cycles in FIG. 1 represents a school term (one semester). The "plan" phase in each cycle consisted of the planning of the course that was made before the action, i.e., the course itself, and was critically based on the results of needs analysis; "action" and "observation" were intertwined and were, therefore, described as one because it was impossible to dissociate one from the other: the action represented the course, that was based on a flexible course design (GRAVES, 2000) and which was influenced by the observations made throughout the course; the "reflection" phase was carried out after the students answered questionnaires at the end of each cycle (APPENDIX B), ${ }^{5}$ and it was influenced by the preceding phases. The results of one cycle influenced the directions taken in the following cycles.

\footnotetext{
${ }^{5}$ Both questionnaires (APPENDIX A and B) were presented to the students in Portuguese and are therefore kept in their original form.
} 


\section{Description of the process}

Based on my experience as a teacher at the Institution and on the results of a preliminary needs analysis questionnaire (APPENDIX A), a flexible course design was prepared. This preliminary Needs Analysis questionnaire was answered by 48 students. As the actual data collection for the research was going to start at the beginning of the following school term, this preliminary questionnaire was used to help me plan the research and the results can be summarized as follows: $98 \%$ of the students considered the English course essential to their future career as engineers; $56 \%$ believed that the course had to be offered to all students, only excluding those who had very good knowledge of English; most were eager to use the computer as a course tool $(83 \%)$ and considered it important to improve the four abilities in this order: reading (73\%); listening (68\%); speaking $(66 \%)$ and writing $(54 \%)$. The students' answers also showed other relevant information, i.e., the students' expectations to attend a course in which they could improve their communicative abilites so as to be able to talk about texts from different sources $(58 \%)$ and to make oral presentations (44\%). The analysis of the students' answers met my expectations as teacher, researcher and course designer and contributed to organize the first course design, which was prepared in the light of Graves' (2000) framework of course development process.

This means that all the items that are part of a course design (aims, materials, content, etc.) could be modified during the course according to the students' feedback. The initial structure of the course design is shown in the following picture:

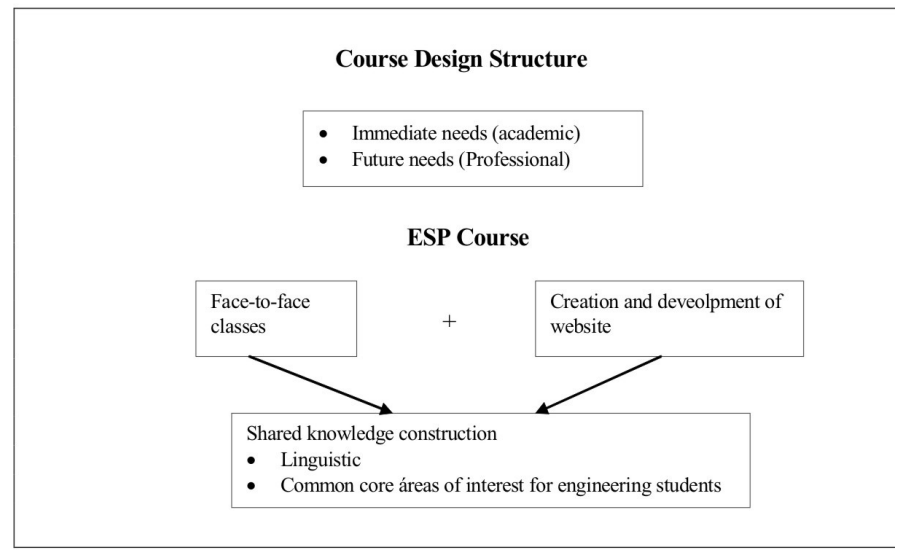

FIGURE 2 - The structure of the course design 
As shown above, from the very beginning of the research, emphasis was given to activities that focused on the students' immediate needs to use the English language (academic needs, such as writing an abstract, searching specialized journals or interacting with foreign students on campus) and on their future needs as engineers (for example, getting ready for a job interview or reading about the profession). The course was held in a face-to-face environment. However, gradually, while the course was in process, a website began to be implemented, with links to on-line dictionaries, specialized magazines and journals of interest to the students, quizzes for engineers (mainly ones that involve logics and math) and also an area in which the students' productions (e.g. assignments prepared in class or at home, pictures) could be uploaded as shown in PICTURE 1.

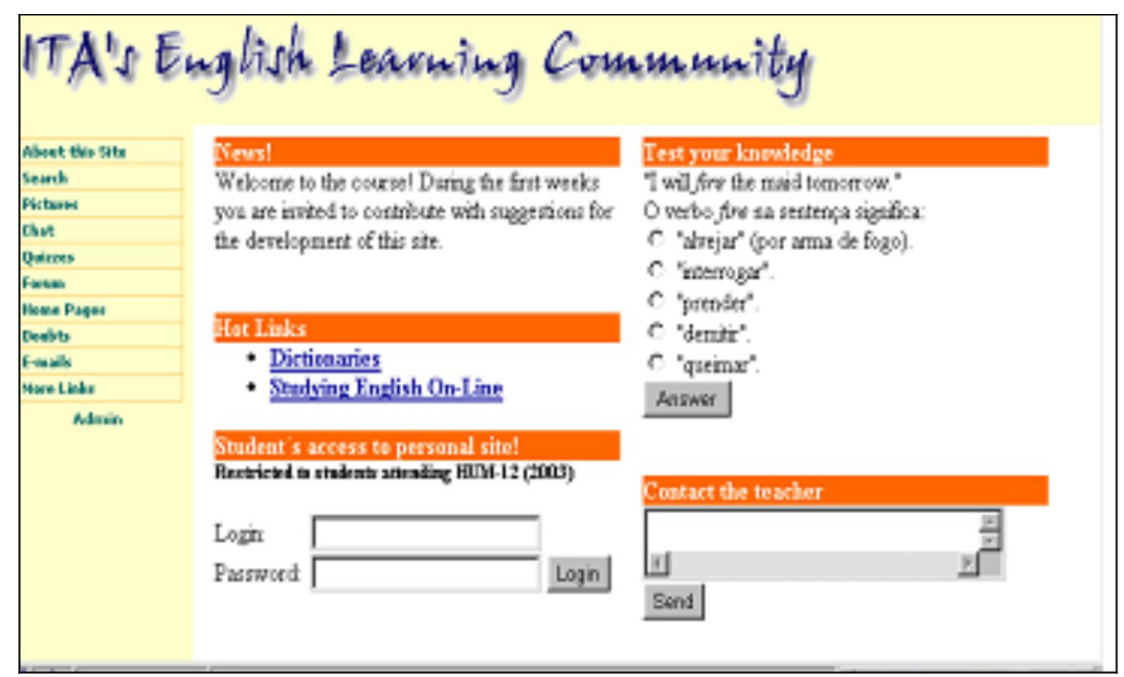

PICTURE 1 - Course's website: first lyout

In this way, it was assumed that the combination of face-to-face classes and the parallel creation and development of a website would enable the construction of shared knowledge both in terms of language and in terms of different areas of interest for engineering students. It is important to observe that the initial website was outlined by me (teacher and researcher) and by an engineering undergraduate student who was not taking the English course at the time but was carrying out a scientific initiation project ${ }^{6}$ under my

${ }^{6}$ Bolsa PIBIC-CNPq. 
supervision. His project consisted on the creation and maintenance of the course's website. The first outline of the site was presented to the class at the beginning of the course and decisions that ranged from the name of the site, the font size and the background page and font colours, to links to be included on the page were taken by the whole group (which included me, the scientific initiation student and the students who were enrolled in the course at the time).

At the end of Cycle1 of the research (first semester), and after analyzing the course evaluation questionnaire answered anonymously by the students (APPENDIX A), it was possible to confirm that they reacted positively to the course in many aspects: choice of course content ( $85 \%$ of acceptance), teacher - students interaction (exemplified in sentences written anonymously in the questionnaires such as a integração da turma, o interesse do grupo; liberdade para tirar dúvidas e uma ajuda muito grande da professora.), ${ }^{7}$ the course's flexibility and the incorporation of the computer to the course design $o$ trabalho em grupo para o portal; elaboração do portal: uma boa idéia. ${ }^{8}$ They pointed out, however, that little emphasis was given to oral production activities and that many of the activities had to be prepared as homework and were time consuming (e.g. Faltou um pouco mais de conversação; muita coisa pra fazer em casa pois a maioria esquecia e atrasava o cronograma). ${ }^{9}$ They mentioned that they had many assignments not only in the English course but in the other disciplines of the curriculum as well. That made me realize, for the first time, the importance that had to be given to the context where the course was being held and this is the reason that lead to the inclusion of means analysis (BENESCH, 1999, 2001).

After the first semester, the website began to reflect the students' production after one semester of the course, as shown in Picture 2, which illustrates links to different assignments prepared by the students in the first semester: a) Projects (in which the students brought to the English class texts from their Physics class related to a water rocket launching experiment. These texts were read and discussed in class and then the students prepared a report in which they documented the day when the experiment was carried out on

\footnotetext{
${ }^{7}$ the group integration, the group interest; freedom to have doubts answered and great help from the teacher.

${ }^{8}$ Group work for the site; site preparation: a good idea.

${ }^{9}$ few conversation activities; too much homework, because most students forgot it and this delayed the schedule.
} 
campus. The report included both descriptions and pictures taken by the students.

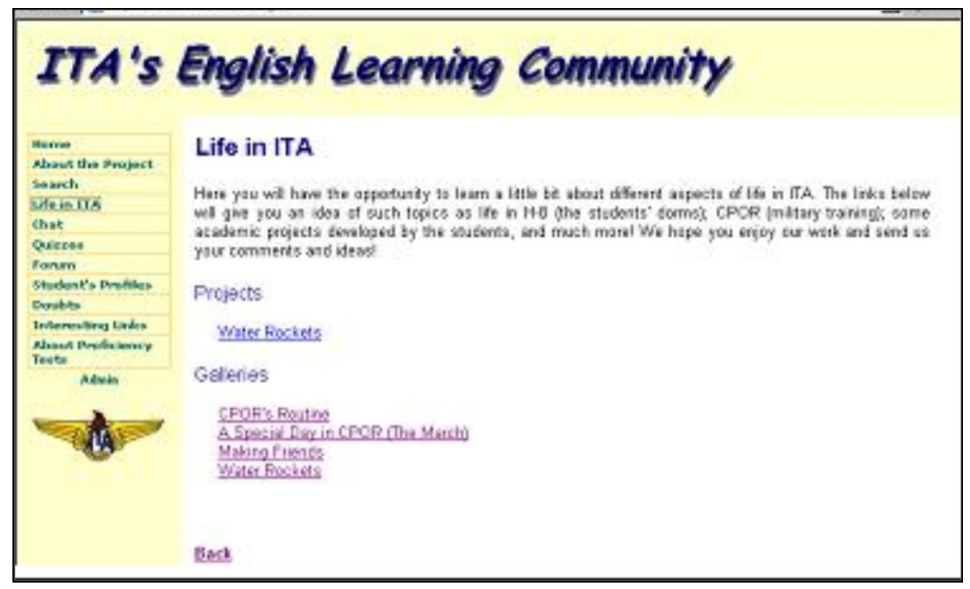

Picture 2 - Example of students' production after one semester

The design of Cycle 2, then, took the students' answers to the evaluation questionnaire into consideration and among the modifications for the following semester, a unit on oral presentations was introduced in the course. Also, some of the activities previously set for homework (e.g. final task of the "abstract writing unit", i.e. a unit in which the final activity was the production of an abstract of the project presented by the students at the Science Exhibition Event), began to be developed, at least partially, in class. At the end of Cycle 2 , once again, following the movements of the action research, as pointed out in the previous section, another questionnaire, similar to the one used at the end of Cycle 1 (APPENDIX B), was answered by the students and new adjustments to the course design were made based on this feedback. The course design was reformulated to Cycles 3 and 4 in the light of a new theoretical insight based on the development of tasks. Ellis (2003, p. 9-10) identifies six critical features of a task: "a task is a work plan; it involves a primary focus on meaning; it involves real-world processes of language use; it can involve any of the four language skills; it engages cognitive processes; and it has a clearly defined communicative outcome." Chapelle (2003, p. 129), in turn, says that "what qualifies a "task" differs from one researcher to another, but across definitions it is generally regarded that tasks must have goals, and that they are carried out through participants' engagement in goal-oriented behaviour that relies at least in part on language." 
The concept of task that underlies the reformulation of the course design for Cycles 3 and 4 was based on the definitions given by these two authors. In the light of their work, a course design that suggested tasks based on themes related to the academic and future professional needs of the students was prepared. The course for the following year, then, focused on four great thematic areas associated with a final task (that represented a defined communicative outcome) and to activities that involved the use of the computer as shown in the table below:

TABLE 1

The structure of the course for Cycles 3 and 4

\begin{tabular}{l|l|l|l}
\hline Bimester & \multicolumn{1}{|c|}{ Theme } & \multicolumn{1}{c}{ Final Task } & \multicolumn{1}{c}{ Use of Computer } \\
\hline First & $\begin{array}{l}\text { Students' new } \\
\text { life at college }\end{array}$ & - Student's profile & $\begin{array}{l}\text { special area in the webpage to be } \\
\text { filled in with personal information }\end{array}$ \\
\cline { 3 - 4 } Second & \multirow{2}{*}{ The profession } & $\begin{array}{l}\text { - Research: different } \\
\text { engineering areas }\end{array}$ & whoto gallery in the site \\
\cline { 3 - 4 } & & $\begin{array}{c}\text { - Interview with } \\
\text { engineering teachers }\end{array}$ & published in the site \\
\hline Third & Academic Life & $\begin{array}{c}\text { - Abstract preparation } \\
\text { (Science Exhibition) }\end{array}$ & $\begin{array}{l}\text { Science Exhibition } \\
\text { homepage preparation }\end{array}$ \\
\hline Fourth & Professional Life & - Oral presentations & instructions in the site \\
\hline
\end{tabular}

The four themes chosen above were the result of the feedback given by the students on the activities developed in the previous year (Cycles 1 and 2). Based on these themes and on the learning needs related to them, the tasks were prepared according to the orientations found in Ellis (2003) and in Chapelle (2003). The computer was integrated to the course design in the light of the critical analyst perspective and its influence on ELT proposed by Chapelle (2003) and discussed above and according to the definition of integrative CALL given by Warschauer (2000, p. 65) “... by allowing and helping our students to carry out all these types of authoring toward fulfilling a meaningful purpose for a real audience we are helping them exercise agency. The purpose of studying English is thus not just to "know it" as an internal system, but to be able to use it to have a real impact on the world".

Therefore, most of the tasks developed in the course were inserted in the course's website, which, in turn, was fed by the students' productions. Also, decisions related to content and to the site's format were taken by the whole 
group, as already explained. It is important to point out that at the end of the first year of this study, the course's site had changed significantly both in content and in layout. With the use of a password, the students enrolled in the course were able not only to access the site and their colleagues' productions but also to upload materials and interact by means of a forum inserted in the site.

The "Abstract preparation activity" which was conducted in Cycle 4 is reproduced below to illustrate the activities that were part of the course and of the site:

The instructions for this activity were prepared in a document and uploaded in the site (PICTURE 3). The exercises, prepared by the students in small groups in class and in the computer laboratory, resulted in the abstract, which later was posted on the site, as shown in PICTURE 4.

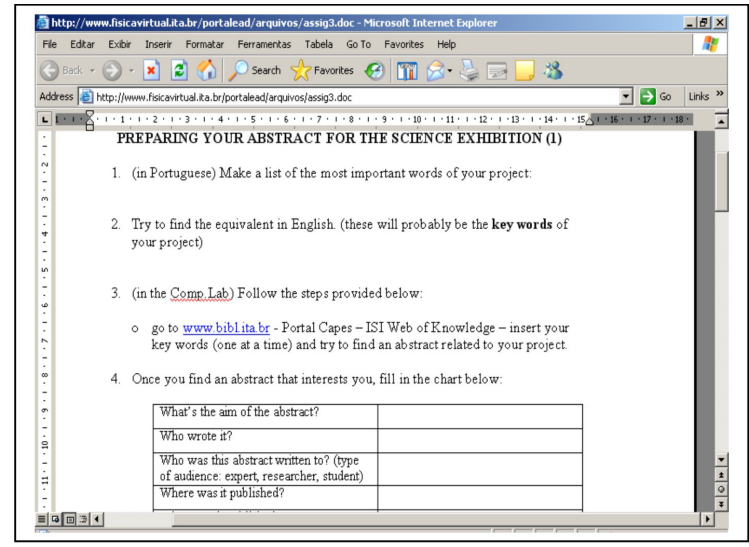

PICTURE 3 - Sample of the guidelines for the task

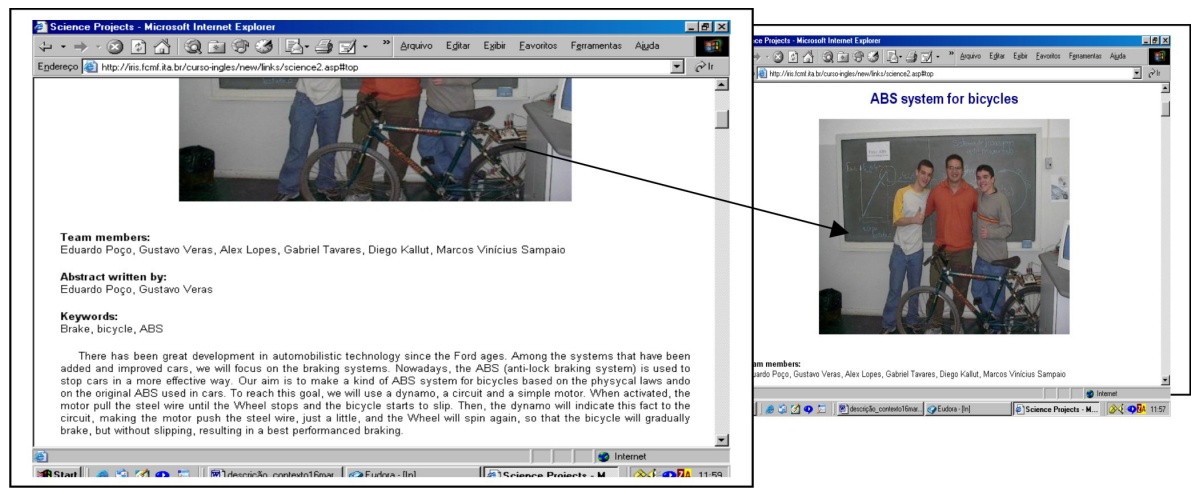

PICTURE 4 - Example of students' production posted in the site. 
It cannot be forgotten that the students in this ESP course were teenagers or young adults. This means that they were all born in the "digital age" and were very familiar to computers in their daily life, mainly for leisure. Incorporating the computer to the course design as a meaningful educational tool was one of the challenges in this research.

At the end of Cycle 3 the course evaluation questionnaire was answered by the students in order to evaluate the course until then. The results indicated positive reactions in terms of the methodology adopted in the course (ótimas atividades em grupo; aula dinâmica; aula tranqüila: não causa stress) ${ }^{10}$ the integration of the four communicative skills (prática de inglês aprendendo a ouvir e a falar; (...) eu consegui aprender muita coisa, aumentei meu vocabulário, aprendi a pronúncia de muitas palavras, etc, $)^{11}$ the use of the computer (muito bom... usando o computador, a aula ficou com uma rotina diferente. $)^{12}$ and the possibility the students had to participate in the decisions about the course $(O$ curso é aberto para ir ao encontro dos interesses da sala). ${ }^{13}$ This positive feedback was essential to the continuation of the course as planned in Cycle 4. At the end of that cycle, once again, the evaluation questionnaire was answered. The analysis of the results showed that the course plan, with the modifications that had been introduced in the second year of the study, was adequate and that the site reflected the tasks prepared by the students within the period, therefore reaching the objectives proposed at the beginning of the study.

The website also reflected the changes that had taken place within the period, as shown in the following picture.

${ }^{10}$ Excellent class activities; dynamic classes; calm classes, they don't stress;

${ }^{11}$ English practice learning to listen and to speak, I learned a lot, increased my vocabulary, learned the pronunciation of many new words, etc.

${ }^{12}$ very good... by using the computer, the course had a different routine.

13 The course is open to meet the group's interests. 


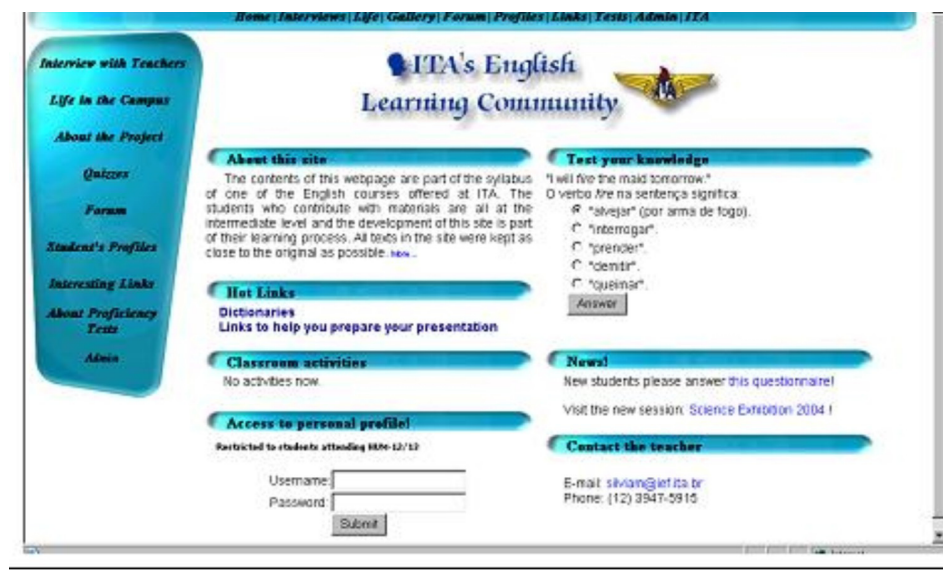

PICTURE 5 - The website at the end of Cycle 4

However, the questionnaires also showed what I had been observing during the "action" and "observation" phases in the last two cycles of this action research: although the students were interested in the English course, appreciated its design and felt motivated to do the tasks, they resented the fact that it was a compulsory discipline in the curriculum. One of the characteristics of action research, as pointed out by Kincheloe (1997), is that it develops the researchers' critical orientation to his/her work and leads him/her to a reflective attitude about his professional life. While Cycles 3 and 4 were in course, I began thinking about new possibilities to the teaching of English in this context. Finally, at the end of Cycle 4, I felt I was mature enough to propose new directions for ESP teaching and learning at the Institution where the research was carried out.

\section{New directions for ESP at the Institution}

The thematic areas and the tasks associated with them to prepare the course design in Cycles 3 and 4 were related to the students' academic and future professional needs. I concluded, however, that there was no need to hold one single course, restricted to first year undergraduates, comprising all the four thematic areas. I realized that it was possible to split these areas into independent thematic units and to prepare different ESP courses that focused either on the students' academic life or on their preparation to their future professional life. Based on this, I submitted a project (which was later approved) to the Institute's administration in which I indicated that the English language course, which until then had been compulsory to the 
freshmen, became an optional discipline in the curriculum to undergraduate students in general. I also recommended a new format to the ESP courses at the Institution: an optional, 32 hour course, as part of the regular curriculum, offered to undergraduates in general (not only to freshmen); or extracurricular courses (approximately 20 hours each), held, under request, any time during the year, focusing on specific areas of students' demands. The tables below illustrate this new format of extracurricular courses in terms of themes and final tasks possibilities:

TABLE 2

Example of thematic course content (academic life)

\begin{tabular}{c|l}
\hline Theme & \multicolumn{1}{|c}{ Final Task } \\
\hline Academic Life & Abstract preparation \\
\cline { 2 - 2 } & Writing: technical papers \\
\cline { 2 - 2 } & Oral presentations (for academic events) \\
\hline
\end{tabular}

TABLE 3

Example of thematic course content (professional life)

\begin{tabular}{c|l}
\hline Theme & Final Task \\
\hline Professional Life & Job interviews \\
\cline { 2 - 2 } & CV, Resume and Cover Letters preparation \\
\hline
\end{tabular}

TAB. 2 and 3 indicate the possibility of offering very specific, genre based ESP courses, as described by Dudley Evans and St. John's (1998) last position of the continuum (Position 5). They also lead to the possibility of using Ramos' (2004) pedagogical proposal of genre based course design to prepare the teaching units. In terms of the students' academic life, for instance, it is possible to design a course that focuses specifically on the preparation of abstracts. It is also possible to prepare another English course that focuses only on oral presentations for academic events. However, if there is the need, the two thematic course contents suggestions above can be put together in one and a course that focuses on abstract preparation and on academic oral presentations can be designed as well. The same thing can be done with courses that focus on students' professional life. A longer term course can be designed focusing on various "final tasks" in the English language that may be relevant for engineers, or a short term course can be prepared, focusing only on CV and Cover Letter preparation, for example, as described in Damião (2009). The website may also be used in the light of the definitions of Warschauer (2000) 
and Chapelle (2003), i.e., as a means of integrating the English course, and the tasks performed in it, to the students' life.

\section{Final considerations}

This action research focused on the design and teaching of an ESP course and on the collaborative construction and development of a website. Based on a preliminary needs analysis and on my experience as an EFL teacher at the institution where the research was carried out, a face-to-face course plan, which also included the construction of a website, was prepared. During the first year of the study, the course plan was reformulated according to the feedback given by the students; also, the site was gradually constructed and modified as the students' productions and class activities were inserted in the site. The initial course plan was gradually modified as the data was collected throughout the trajectory of the research in the first year of the study. These continued needs analysis (DUDLEY EVANS; St. JOHN, 1998) rights analysis (BENESCH, 1999, 2001), and negotiation (BREEN; LITTLEJOHN, 2001) processes led to significant changes in the second year of the research. It was then that the course plan was reformulated in the light of a new theoretical background based on tasks (ELLIS, 2003; CHAPELLE, 2003) chosen according to themes, which, in turn, were established according to academic and future professional needs identified at the beginning of the research. At the end of the second year, it was possible to confirm that the course plan, with the changes that were implemented during the time of the research, was adequate, and that the site also incorporated the students' productions. This means that, after carrying out this action research, it was possible to propose an ESP course (or ESP courses) in which tasks and genre based activities articulate different language skills not to forget the insertion of the computer within the context.

However, these two-years, four cycles action research trajectory was not a simple process. At the beginning of the project it was very clear to me, both as teacher and researcher, that at the end of the research I would come to an "ideal" course plan for the context. I had identified problems in the English course for the freshmen at the Institution (e.g. unattended students' needs, students who were unsatisfied with the course plan) and I believed that the design of a course plan, associated with the incorporation of technological resources, more specifically, to a course website, would effectively solve the problem. I also believed that the action research would help me reach my aims. 
It cannot be denied that the aims of the research were effectively reached. However, the whole process made me gradually reorganize and reinterpret the reasons for the research and also helped me to see new possibilities for my work. Although the students' feedback indicated that the course was adequate for their needs and that the incorporation of a website represented a great contribution for their learning process, it was evident that the English course was not adequately inserted in the institutional curriculum as a whole, i.e., the course was "in the wrong place" and was not adequate as a compulsory discipline for first year engineering undergraduates.

This process also made me understand the cognitive benefits that, according to Kincheloe (1997), can be reached by the researcher who effectively conducts an action research. According to him, the action research leads the researcher to a critical understanding of his own work, making him develop a reflexive attitude to his professional life. And it is evident that it was only in the second year of the study that my understanding of the institutional context began to change and I was able (and prepared) to implement changes in the EFL curriculum.

Finally, it is important to emphasize that further studies should be carried out in this area, both at the Institution where this research took place, and elsewhere. It would be helpful to analyze the results of this new ESP course structure and to implement similar projects at other environments as well.

\section{References}

BENESCH, S. Rights analysis: studying power relations in an academic setting. English for specific purposes, v. 18, n.1, p. 313-327, 1999.

BENESCH, S. Critical English for academic purposes: theory, politics and practices. Mahwah, New Jersey: Lawrence Erlbaum Associates, 2001. 161p.

BLOOR, M. The English language and ESP teaching in the $21^{\text {st }}$ century. In: MEYER F.; BOLIVAR A.; FEBRES J.; SERRA M. B. (Ed.). English for Specific Purposes in Latin America. Merida, Venezuela: Unversidad de Los Andes, 1997. BREEN, M.P.; LITTLEJOHN, A. The significance of negotiation. In: BREEN, M.P.; LITTLEJOHN, A. Classroom Decision Making: negotiation and process syllabuses in practice. Cambridge University Press, 2000. p. 5-38.

BURNS, A. Action research. In: HINKEL, E. (Ed.). Handbook of research in second language teaching and learning. Mahwah, N. Jersey: Lawrence Erlbaum Associates, Inc. Publishers, 2005. p.241-262. 
CARDOSO, Z. C. Análise de necessidades no setor de recepção de hotel: primeiro passo para uma proposta de curso. 2003. 131f. Dissertação (Mestrado em Linguística Aplicada e Estudos da Linguagem) - Programa de Estudos PósGraduados em Linguística Aplicada e Estudos da Linguagem. Pontifícia Universidade Católica de São Paulo, São Paulo, 2003.

CARVALHO, K. R. R. Análise de Necessidades para a disciplina língua inglesa em um curso de Letras. 2008. 234f. Tese (Doutorado em Linguística Aplicada e Estudos da Linguagem) - Programa de Estudos Pós-Graduados em Linguística Aplicada e Estudos da Linguagem. Pontifícia Universidade Católica de São Paulo, São Paulo, 2008.

CELANI, M. A. A. et al. The Brazilian ESP Project: an evaluation. Centro de Pesquisas, Recursos e Informação em Leitura, PUC, São Paulo, Brasil - São Paulo: EDUC, 1988. 166p.

CELANI, M. A. A. Introduction. In: CELANI, M. A. A.; DEYES, A.; HOLMES, J.; SCOTT, M. ESP in Brazil: 25 Years of Evolution and Reflection. São Paulo: EDUC e Mercado de Letras, 2005. p.13-26.

CHAPELLE, C. English language learning and technology: lectures on applied linguistics in the age of information and communication technology. John Benjamins Publishing Company, 2003. 211p.

CROOKES, G. Action research for second language teachers: going beyond teacher research. Applied Linguistics, v. 14 n.2, p. 130-144, 1993.

DAMIÃO, S.M. Curso de curta duração para alunos de Engenharia: uma experiência de desenho de curso presencial e a distância. In: SIGET SIMPÓSIO INTERNACIONAL DE ESTUDOS DE GÊNEROS TEXTUAIS: O ENSINO EM FOCO, 5, 2009, Caxias do Sul. Anais... Caxias do Sul, RS. Disponível em: <http://www.ucs.br/ucs/tplSiget/extensao/agenda/eventos/ vsiget/portugues/anais/textos_autor/arquivos/curso_de_curta_duracao_ para_alunos_de_engenharia_uma_experiencia_de_desenho_de_curso.pdf $>$. Acesso em: 27 fev. 2011.

DUDLEY EVANS, T.; ST. JOHN, M. Developments in ESP: a multidisciplinary approach. Cambridge University Press, 1998. 297p.

ELLIS, R. Task-based language learning and teaching. Oxford: Oxford University Press, 2003. 387p.

GRAVES, K. Designing Language Courses: a guide for teachers. Heinle and Heinle, Thomson Learning, 2000. 307p.

HUTCHINSON, T.; WATERS, A. English for Specific Purposes. Cambridge University Press, 1987. 183p. 
KEMMIS, S.; MC TAGGART, R. (Ed.). The action research planner. Geelong, Victoria, Australia: Deakin University Press, 1988. 154p.

KINCHELOE, J. L. A formação do professor como compromisso político: mapeando o pós moderno. Porto Alegre: Artmed, 1997. 262p.

MCKERNAN, J. Curriculum action research. London: Kogan Page, 1991. 276p. PINTO, M. M. O inglês no mercado de trabalho do secretário executivo bilingüe: uma análise de necessidades. 2002. 139f. Dissertação (Mestrado em Lingüística Aplicada e Estudos da Linguagem) - Programa de Estudos Pós-Graduados em Linguística Aplicada e Estudos da Linguagem, Pontifícia Universidade Católica de São Paulo, São Paulo, 2002.

RAMAL, A.C. Educação na cibercultura: hipertextualidade, leitura, escrita e aprendizagem. Porto Alegre: Artmed, 2002. 268p.

RAMOS, R.C.G. Gêneros Textuais: proposta de aplicação em cursos de inglês para fins específicos. The ESPecialist. v. 25, n. 2, p. 107-129, 2004.

RAMOS, R.C.G. Instrumental no Brasil: a desconstrução de mitos e a construção do futuro. In: FREIRE, M. M.; ABRAHÃO, M. H. V.; BARCELOS, A.M.F. (Ed.). Linguistica Aplicada e contemporaneidade. São Paulo: ALAB; Campinas: Pontes, 2005. p. 109-123.

RAMOS, R. C. G. ESP in Brazil: history, new trends and challenges. In: KRZANOWSKI, M. (Ed.). ESP and EAP in Developing and in Least Developing Countries. IATEFL, 2008. p. 68-83.

ROBINSON, P. ESP Today: a Practitioner's Guide. UK. Prentice Hall International, 1991. 149p.

THIOLLENT, M. Metodologia da pesquisa-ação. São Paulo: Cortez, 2002. 107p. VAN LIER, L. Interaction in the language curriculum: awareness, autonomy and authenticity. New York: Addison-Wesley Longman Limited, 1996. 248p.

WARSCHAUER, M.; HEALEY, D. Computers and language learning: An overview. Language Teaching, v. 31, p. 57-71, 1998. Retrieved: February 9, 2010 from: <http://www.gse.uci.edu/person/warschauer_m/overview.html>.

WARSCHAUER, M. The death of cyberspace and the rebirth of CALL. English Teachers' Journal, v. 53 p. 61-67. 2000. Retrieved: February 9, 2010 from: <http://www.gse.uci.edu/person/warschauer_m/cyberspace.html>.

Recebido em 27/2/2011. Aprovado em 17/6/2011. 